be only a measure of mucosal damage. In this connexion it is worth mentioning that the small-intestinal mucosa is frequently abnormal in ulcerative colitis, and the degree of abnormality is positively correlated with the clinical severity of the colitis (Salem et al., 1964, 1965). This raises the possibility that absorption of whole protein may occur from the small intestine, with resulting high levels of antibody that are then no more than an indication that the intestine has been widely affected, which in turn may indicate a relatively bad prognosis.

Circulating antibodies to dietary proteins are present from birth and can be demonstrated in cord blood, commonly at a higher titre than in maternal blood (Wright et al., 1962). When infants are weaned and fed on cow's milk the levels of circulating antibodies to cow's-milk proteins rise considerably (Gunther et al., 1962). In ulcerative colitis, in coeliac disease, and in idiopathic steatorrhoea the titre of circulating antibodies to various dietary proteins are often high (Taylor and Truelove, 1961; Taylor et al., 1961, 1964). So far as ulcerative colitis is concerned, early weaning from the breast was found to be twice as common in the subjects of this disease as in control subjects (Acheson and Truelove, 1961). There is the possibility that immunological stimulation by dietary proteins during infancy may set the stage for a variety of diseases in later life and that ulcerative colitis is one of them.

\section{Summary}

While making a controlled therapeutic trial of three types of diet in ulcerative colitis, the opportunity was taken to study the levels of circulating antibodies to various dietary proteins throughout the one-year trial period. Serial observations have been made on 51 of these patients, the sera being taken at monthly intervals and tested for antibodies to whole cow's milk, casein, $\alpha$-lactalbumin, $\beta$-lactoglobulin, gluten fraction III, and ovalbumin.
The titres of circulating antibodies to the various dietary proteins bore no close relationship to one another in the individual patients.

There was little fluctuation in antibody titre throughout the period of study, and the occurrence of a relapse of ulcerative colitis, the use of corticosteroids in therapy, and the exclusion or reintroduction of specific items from the diet had no consistent effect on the titres.

For the 51 patients as a group there was a highly significant association between a high titre of circulating antibodies to whole milk and multiple relapses of colitis occurring during the trial period. A similar though less pronounced relationship was also found with $\alpha$-lactalbumin.

In the individual case clinical evidence of hypersensitivity to milk could not be predicted from the antibody level.

The significance of these findings is discussed in relation to the possibility of ulcerative colitis being an allergic disease.

\section{REFERENCES}

Acheson, E. D., and Truelove, S. C. (1961). Brit. med. F., 2, 929.

Boyden, S. V. (1951) f. exp. Med., 93,107.

Frazer, A. C., Fletcher, R. F., Ross, C. A. C., Shaw, B, Sammons, H. G., and Schneider, R. (1959). Lancet, 2, 252.

Gunther, M., Aschaffenburg, R., Matthews, R. H., Parish, W. E., and Coombs, R. R. A. (1960). Immunology, 3, 296.

Cheek, E., Matthews, R. H., and Coombs, R. R. A. (1962). Int. Arch. Allergy, 21, 257.

Salem, S. N., Truelove, S. C., and Richards, W. C. D. (1964). Brit. med. F., 1, 394.

Saperstein, S., Anderson, D. W., jun., Goldman, A. S., and Kniker, W. T. (1963). Pediatrics, 32, 580 .

Taylor K. Thomson D. L., Truelove, S. C., and Wright, R. (1961) Brit. med. f., 2, 1727.

— and Truelove, S. C. (1961). Ibid., 2, 924.

Wright, R., Taylor, K. B., Truelove, S. C., and Aschaffenburg, R. (1962) Brit. med. F., 2, 513 .

and Truelove, S. C. (1965). Ibid.

\title{
Plasma Renin Concentration in Human Hypertension. 1: Relationship Between Renin, Sodium, and Potassium
}

\author{
J. J. BROWN,* M.B., B.S., B.SC., M.R.C.P. ; D. L. DAVIES, * M.B., B.S. ; \\ A. F. LEVER,* M.B., B.S., B.SC., M.R.C.P. ; J. I. S. ROBERTSON,* M.B., B.S., B.SC., M.R.C.P.
}

Brit. med. F., 1965, 2, 144-148

The demonstration by Goldblatt et al. (1934) that hypertension could be produced experimentally by renal artery constriction revived interest in the earlier observation by Tigerstedt and Bergman (1898) that the kidneys contained a substance, renin, which had a pressor effect on intravenous injection. It was later suggested that when the renal artery was narrowed renin was released from the kidney into the circulation and acted upon plasma substrate to produce the pressor peptide angiotensin, which then raised the arterial pressure by direct vasoconstrictor effect (see Braun-Menéndez et al., 1946). Goldblatt $(1947,1964)$ proposed that a similar mechanism was responsible for " essential" hypertension, in which he surmised that multiple intrarenal arterial constrictions were present, corresponding to the experimental renal artery clip.

These theories have been subject to considerable attack-see reviews by Page and Bumpus (1961) and by Pickering and Peart (1964)-largely because several workers have failed to

* Medical Unit, St. Mary's Hospital, London. demonstrate renin or ang:otensin in experimental hypertension in quantities sufficient to account for the hypertension by direct pressor effect (Blacquier et al., 1960 ; Scornik and Paladini, 1961 ; Peart et al., 1961 ; Langford, 1963).

Goldblatt (1937) showed that experimental renal hypertens:on was dependent upon an intact adrenal gland. Floyer (1951) confirmed this, and also demonstrated that renal hypertension which had been abolished by adrenalectomy could be restored by giving sodium chloride.

The subsequent proposal by Gross (1958) that the reninangiotensin system might serve to regulate aldosterone secretion revived interest in this field, since aldosterone-secreting adrenal tumours were known to cause hypertension (Conn, 1955). Subsequently, independent studies by three groups demonstrated that angiotensin infusions caused increased aldosterone production in both man and the dog (Genest et al., 1960a, 1960b; Laragh et al., 1960a ; Mulrow and Ganong, 1961). 
A large body of evidence has since accumulated in support of the concept that the renin-angiotensin system has a controlling influence on aldosterone secretion (Bartter et al., 1961 ; Davis, 1962 ; Blair-West et al., 1962 ; Mulrow et al., 1962 ; Brown et al., 1963a, 1964b ; Scornik and Paladini, 1964). In spite of these observations, the role of renin, angiotensin, and aldosterone in many forms of clinical hypertension remains obscure.

The purpose of the present work was to survey plasma renin concentration in a large number of patients with hypertension so as to indicate those types most profitable for detailed study. The results of preliminary analysis of some of these cases have been reported previously (Brown et al., 1963b, 1964b, 1964c, 1965a). This paper is concerned with the interrelation of renin and plasma electrolytes in hypertension.

\section{Methods}

The 253 patients (135 males, 118 females) studied were aged between 10 and 80 . The series contained examples of aortic coarctation, phaeochromocytoma, Cushing's syndrome, Conn's syndrome, and a wide variety of renal lesions, including chronic glomerulonephritis, renal infection, renal calculi, hydronephrosis, and renal artery stenosis. In addition the series included cases in which no underlying cause for the hypertension had been disclosed by intravenous pyelography, renal arteriography, urine culture, and estimation of the plasma electrolytes.

Medical treatment included ganglion-blocking and sympatholytic drugs, methyldopa, reserpine, thiazide diuretics, and spironolactone both singly and in various combinations. The term "untreated" has been taken to indicate either that the patient had never been treated or that all hypotensive drugs had been withdrawn (in the case of thiazides or spironolactone, for a minimum period of three weeks).

Except where otherwise stated, blood samples were taken from a peripheral vein with the subject sitting or lying. Plasma renin concentration was estimated by an enzyme kinetic technique (Lever et al., 1963, 1964 ; Brown et al., 1964a). This has been sensitive enough for the measurement of renin in all normal persons studied and in conditions where renin is depressed. It may be used with volumes of plasma from 5 to $25 \mathrm{ml}$. Recovery of added renin in all the hypertensive syndromes included in this paper was in the range found with normal plasma (Brown et al., 1964a).

Renin concentration is expressed in arbitrary units (Lever et al., 1964 ; Brown et al., 1964a), the results obtained in the patients with hypertension being compared with values $($ mean $=8.2$; S.D. 2.7 units/1.) in 125 normal subjects aged between 17 and 72 .

Where more than one estimation of plasma renin concentration was made on any patient the mean was taken except where otherwise stated. In all the statistical calculations renin was given a maximum value of 100 units $/ 1$.

Plasma sodium and potassium were measured by flame photometry. Sodium was expressed to the nearest $1 \mathrm{mEq} / 1$. and potassium to the nearest $0.1 \mathrm{mEq} / 1$.

Aldosterone secretion rates were measured either by the method of Cope et al. (1961) or by a modification (see Barraclough et al., 1965) of that of Brooks (1960). Plasma aldosterone was measured by a modification (R. Fraser and V. H. T. James, unpublished) of the method of Kliman and Peterson (1960).

\section{Results}

\section{Renin in Relation to Blood-pressure in Untreated Patients}

Table I shows an analysis of plasma renin in 123 untreated patients with hypertension of varied aetiology. In all cases the diastolic pressure was $100 \mathrm{~mm}$. Hg or higher. The mean renin concentration was significantly higher than the normal mean in the two groups with diastolic pressures above $119 \mathrm{~mm}$. $\mathrm{Hg}$ $(\mathrm{P}<0.001)$, but not in those patients with diastolic pressures in the range $100-119 \mathrm{~mm}$. $\mathrm{Hg}(\mathrm{P}>0.1)$.

\begin{tabular}{|c|c|c|c|c|}
\hline Diastolic pressure $(\mathrm{mm}$. & $\mathbf{H g}):$ & $100-119$ & $120-140$ & $>140$ \\
\hline $\begin{array}{l}\text { No. of patients ... } \\
\text { Plasma renin (units/l.) mean } \\
\text { S.E. of mean for renin .. }\end{array}$ & $\begin{array}{l}\because \\
\because \\
\cdots\end{array}$ & $\begin{array}{c}28 \\
9 \cdot 89 \\
1 \cdot 22\end{array}$ & $\begin{array}{c}65 \\
14 \cdot 17 \\
0.86\end{array}$ & $\begin{array}{r}30 \\
16 \cdot 60 \\
4 \cdot 54\end{array}$ \\
\hline
\end{tabular}

There were, however, within each of the three groups as arranged by diastolic pressure, numerous cases with normal or low plasma renin concentration. The greatest variation in renin concentration was seen in the group with the highest pressure.

\section{Renin in Relation to Plasma Sodium in Hypertension}

An inverse relationship between sodium balance and plasma renin concentration has previously been demonstrated in a variety of conditions in which the blood-pressure is either normal or low. Thus in the normal subject plasma renin is elevated by sodium deprivation and depressed by sodium loading ; plasma renin is high in untreated Addison's disease, but falls as the electrolyte abnormalities are corrected ; in sodiumlosing renal disease the high plasma renin concentration (associated with demonstrably increased aldosterone secretion in a number of patients we have studied) is returned to normal by sodium repletion; and in several cases of congestive cardiac failure an initially low plasma renin concentration has risen following diuretic therapy (Brown et al., 1963a, 1963b, 1964a, 1964b, 1964c, 1964d, 1964e, and unpublished observations).

These findings suggested that a similar inverse relationship might exist in hypertension. Simultaneous plasma renin and plasma sodium estimations were available in 92 untreated patients with various forms of hypertension. There was found to be a highly significant negative correlation between the initial renin and sodium measurements in these cases (correlation coefficient $(\mathbf{r})=-0.530 ; \mathrm{P}<0.001)$.

In several patients serial estimations of plasma renin and sodium were made before starting treatment ; inclusion of the additional data confirmed the inverse relationship between renin and sodium (139 pairs of observations in 92 patients; $r=-0.590 ; P<0.001)$.

When the latter group was restricted by eliminating those cases with plasma sodium less than 135 or more than $144 \mathrm{mEq} / 1$. the figures remained highly significant (104 pairs of observations in 72 patients $; r=-0.311 ; P<0.01$ ).

A further correlation was made of all available simultaneous renin and sodium measurements in hypertensive patients, irrespective of aetiology, complications, treatment, or bloodpressure level at the time of sampling. The results are summarized in Fig. 1, which is based on a total of 399 sets of observations made on 253 patients : 216 pairs of observations were in men and 183 in women. As is apparent from the figure, there was a highly significant negative correlation between renin and sodium $(\mathrm{r}=-0.472 ; \mathrm{P}<0.001)$.

The mean plasma renin concentration did not differ significantly from the normal mean of 8.2 units/1. (Brown et al., $1964 a)$ in any of the six categories of plasma sodium from 140 to $145 \mathrm{mEq} / 1$. (Fig. 1). The mean plasma renin concentration was significantly higher than the normal mean in the patients with a plasma sodium of $139 \mathrm{mEq} / 1 .(t=6.38 ; P<0.001)$ and significantly lower than the normal mean in those with a plasma sodium of $146 \mathrm{mEq} / 1 .(\mathrm{t}=2.85 ; \mathrm{P}<0.01)$. In the hypertensive series renin concentration became progressively more abnormal with increasing divergence of plasma sodium from the range $140-145 \mathrm{mEq} / 1$. 
Wootton and King (1953) found that in $80 \%$ of normal subjects plasma sodium was between 137 and $148 \mathrm{mEq} / 1$. Fawcett and Wynn (1956) found considerably less variation, but were careful to point out that the ages of the subjects studied by them were less diverse than those in the series of Wootton and King. It is interesting that the mean plasma sodium in our untreated hypertensive patients $(141.1$; S.E. $0.27 \mathrm{mEq} / 1$.) is very close to the values found by Fawcett and Wynn in normal persons (mean for $\mathrm{men}=141.7$; for women $=140.5 \mathrm{mEq} / 1$. in their study).

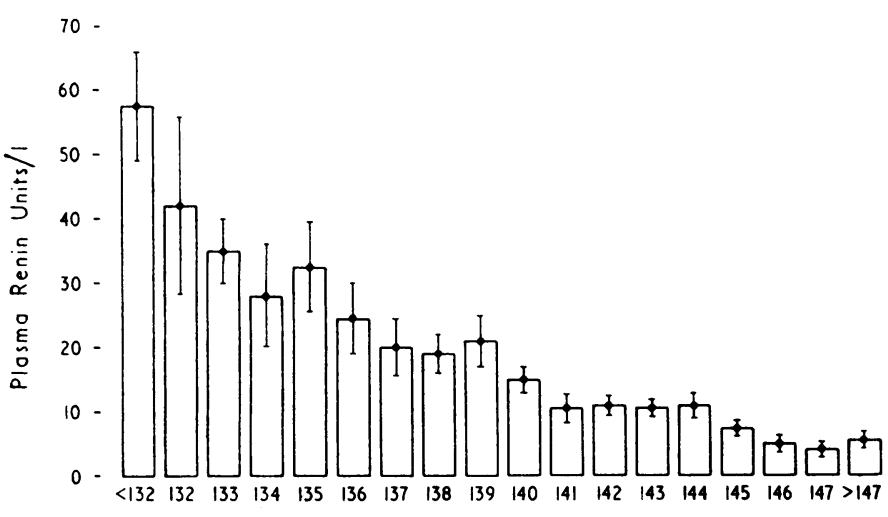

$$
\text { Plosmo } \mathrm{No}^{+} \mathrm{mEq} / \mathrm{I} \text {. }
$$

FIG. 1.-Relationship between plasma renin concentration and plasma sodium for entire series, treated and untreated included. Mean and S.E. shown for renin. (N.B.: The mean and S.E. of the renin values in the patients with plasma sodium less than 132 would both be considerably greater than shown if renin had not been assigned a maximum value of 100 units per litre.)

The present data provide evidence in a series of patients with hypertension of a constant inverse relationship between plasma sodium and renin concentration. The correlation is independent of aetiology, of the severity of the hypertension, and of treatment, and appears to extend through the normal range of both sodium and renin. It is of interest, however, to consider briefly syndromes at the opposite ends of this spectrum.

\section{Syndrome of Hypertension with Hyponatraemia and Increased Plasma Renin Concentration}

Numerous descriptions have been published of cases of severe hypertension associated with many or all of the following features: loss of weight, polyuria, polydipsia, hypokalaemia, and hyponatraemia (Bauer and Forbes, 1952; Wyngaarden et al., 1954 ; Deming, 1954 ; Dollery et al., 1959). A further feature was added when Holten and Petersen (1956) reported increased aldosterone excretion in a case of this type. Increased aldosterone excretion and secretion was subsequently confirmed in similar cases by several workers (Fitzgerald et al., 1957; Wrong, 1957 ; Laragh et al., 1960b ; Yamauchi et al., 1961 ; Gowenlock and Wrong, 1962). Renal artery stenosis has been present in many examples, and either retinal or histological evidence of the malignant phase has been an almost invariable finding, in contrast to its comparative rarity (but not absence) in primary aldosteronism.

This syndrome, which for convenience we shall subsequently call the "hyponatraemic hypertensive syndrome," is the one form of untreated clinical hypertension in which we have found plasma renin concentration consistently raised. Some details of 25 patients showing features of this syndrome are given in Table II. All had bilateral retinal haemorrhages and exudates and/or papilloedema and/or fibrinoid arteriolar necroses. All had a high plasma renin concentration (range 19-1,920 units/1.). Aldosterone secretion rate was increased in the three patients of the group in whom it was measured. All 25 had renal disease, which included renal artery narrowing or occlusion in 17 and advanced renal failure in seven.

\begin{tabular}{|c|c|c|c|c|}
\hline $\begin{array}{l}\text { Plasma } \\
\text { Renin } \\
\text { Concen- } \\
\text { tration } \\
\text { (units } / 1 .)\end{array}$ & $\begin{array}{c}\text { Plasma } \\
\mathrm{Na} \\
(\mathrm{mEq} / 1 .)\end{array}$ & $\begin{array}{c}\text { Plasma } \\
\mathrm{K} \\
(\mathrm{mEq} / 1 .)\end{array}$ & $\begin{array}{l}\text { Blood } \\
\text { Urea } \\
\text { (mg./ } \\
100 \mathrm{ml} .)\end{array}$ & Diagnosis \\
\hline $\begin{array}{l}1,920^{*} \\
240 \\
146 \\
95 \\
84 \\
83^{*} \\
82 \\
72 \\
68 \\
61\end{array}$ & $\begin{array}{l}129 \\
127 \\
129 \\
120 \\
133 \\
132 \\
135 \\
136 \\
138 \\
138\end{array}$ & $\begin{array}{l}2 \cdot 9 \\
4 \cdot 0 \\
3 \cdot 9 \\
4 \cdot 2 \\
3 \cdot 7 \\
2 \cdot 4 \\
3 \cdot 9 \\
3 \cdot 3 \\
3 \cdot 2 \\
3 \cdot 4\end{array}$ & $\begin{array}{r}34 \\
175 \\
66 \\
180 \\
42 \\
35 \\
35 \\
51 \\
30 \\
65\end{array}$ & $\begin{array}{l}\text { Renal artery stenosis } \\
\text { Nephrocalcinosis } \\
\text { Renal artery thrombosis } \\
\text { "’ ,", } \\
\text { Renal artery stenosis } \\
\text { Renal artery thrombosis } \\
\text { Renal artery stenosis } \\
\text { Renal artery thrombosis } \\
\text { Renal artery stenosis } \\
\text { Probable chronic glomerulo- } \\
\text { nephritis }\end{array}$ \\
\hline $\begin{array}{l}46 \\
43 \\
40 \\
40^{*} \\
38 \\
35 \\
33 \\
31 \\
30 \\
29\end{array}$ & $\begin{array}{l}129 \\
122 \\
134 \\
138 \\
126 \\
134 \\
132 \\
138 \\
138 \\
134\end{array}$ & $\begin{array}{l}4 \cdot 0 \\
3 \cdot 1 \\
5 \cdot 3 \\
3 \cdot 0 \\
6 \cdot 9 \\
3 \cdot 4 \\
3 \cdot 9 \\
3 \cdot 1 \\
3 \cdot 1 \\
2 \cdot 9\end{array}$ & $\begin{array}{r}42 \\
225 \\
264 \\
20 \\
645 \\
43 \\
35 \\
53 \\
57 \\
210\end{array}$ & $\begin{array}{l}\text { Renal artery stenosis } \\
\text { Advanced malignant phase } \\
\text { ? Polyarteritis } \\
\text { Renal artery stenosis } \\
\text { Chronic glomerulonephritis } \\
\text { Unilateral hydronephrosis } \\
\text { Renal artery stenosis } \\
\text { "” " ", } \\
\text { Probable chronic glomerulo- }\end{array}$ \\
\hline $\begin{array}{l}26 \\
24 \\
24 \\
22 \\
19\end{array}$ & $\begin{array}{l}136 \\
135 \\
140 \\
132 \\
140\end{array}$ & $\begin{array}{l}2 \cdot 7 \\
3 \cdot 1 \\
3 \cdot 0 \\
2 \cdot 7 \\
3 \cdot 2\end{array}$ & $\begin{array}{r}42 \\
48 \\
36 \\
250 \\
60\end{array}$ & $\begin{array}{l}\text { Renal artery stenosis } \\
\text { ", ", ", } \\
\text { Chronic glomerulonephritis } \\
\text { Renal artery stenosis }\end{array}$ \\
\hline
\end{tabular}

* Increased aldosterone secretion demonstrated. Respective rates were 1,197, 1,028 , and $375 \mu \mathrm{g} .24$ hours (normal 45-160 $\mu \mathrm{g} . / 24$ hours; Barraclough et al., 1965).

Sixteen of the 25 had a plasma potassium below $3.5 \mathrm{mEq} / 1$. Plasma sodium was below the normal mean in all, and 135 $\mathrm{mEq} / \mathrm{l}$. or lower in 16 . There was a significant inverse relationship within the group between plasma sodium and renin concentration $(\mathrm{r}=-0.448 ; 0.05>\mathrm{P}>0.02)$.

\section{Hypertension with Hypernatraemia and Decreased Plasma Renin Concentration}

Hypertension with hypernatraemia and abnormally low plasma renin concentration may occur in Conn's syndrome (Brown et al., 1963b, 1964f) and in Cushing's syndrome (Brown et al., 1965b). In both conditions the depression of plasma renin appears to be closely connected to the increase in sodium. Thus in Conn's syndrome plasma renin concentration has been shown to be elevated to normal by spironolactone treatment, which can correct the electrolyte abnormalities, while leaving the aldosterone secretion rate unaltered (Brown et al., 1963b, 1964f, $1965 \mathrm{c})$; and prolonged administration of potassium chloride supplements may be accompanied by a correction of both the hypernatraemia and low plasma renin, although hypokalaemia may persist (Brown et al., 1964f, 1965c). It is also possible that hypernatraemia, with similar depression of plasma renin concentration, could occur in hypertension as a result of lesions other than primary tumours or hyperplasia of the adrenal cortex (see Brown et al., 1964f, 1965c).

\section{Plasma Renin in Hypertension with Demonstrated Excess of Aldosterone}

From the preceding paragraphs it is evident that increased aldosterone production in hypertensive patients will occur with both abnormally high and abnormally low plasma renin concentration.

Fig. 2 shows the plasma renin in 10 hypertensive patients with a demonstrated excess of aldosterone (increased secretion rate and/or increased plasma level and/or aldosteronoma found at operation). The three with high renin levels all had severe hypertensive retinopathy and unilateral main renal artery stenosis.

By contrast, none of the seven patients with very low plasma renin concentration had retinal haemorrhages or exudates, 
although arteriolar fibrinoid lesions were found on renal biopsy in two of them (Brown et al., 1964f, 1965c; Brown, Davies,

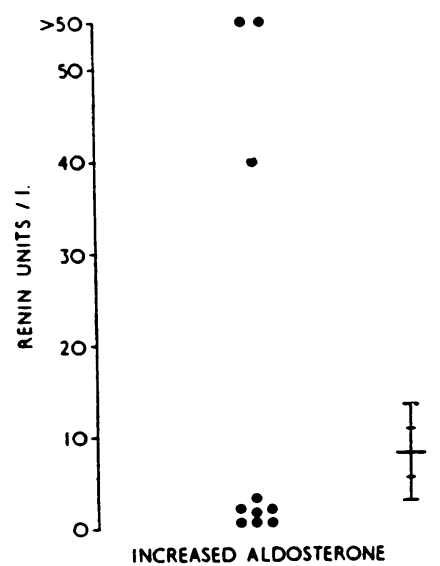

FIG. 2.-Plasma renin concentrations in 10 patients with demonstrated increase in aldosterone. Normal mean, 1 S.D., and 2 S.D. also indicated. Lever, and Robertson, to be published). This group includes three patients from whom Conn's tumours were subsequently removed, and two further patients currently under investigation in whom this diagnosis is highly likely. The sixth patient, a woman with fibromuscular hyperplasia of the renal arteries, may well have an adrenal tumour, which could not be found at operation. This patient, reported on and discussed previously, has for over two years been free of symptoms, with normal bloodpressure and electrolytes, on spironolactone therapy (Brown et al., 1963b, 1964b, 1964c). The seventh patient, who is not under our personal care, is reported to have recovered from her hypokalaemic tendency after control of the hypertension with methyldopa and guanethidine. So far it has not been possible to reinvestigate this case.*

All of these 10 cases had hypokalaemia (plasma potassium $<3.5 \mathrm{mEq} / 1$.). The three with high renin had hyponatraemia (mean plasma sodium $133.0 \mathrm{mEq} / \mathrm{l}$.), while the seven with low renin had hypernatraemia (mean plasma sodium $146.7 \mathrm{mEq} / 1$.).

\section{Plasma Renin in Hypertension with Hypokalaemia}

From the previous comments it will be apparent that plasma renin concentration in hypertensive patients with hypokalaemia may be either abnormally high or low, having a distribution very similar to that shown in Fig. 2 (Brown et al., 1963b, 1964b, 1964c).

\section{Effect of Thiazides}

Analysis of those patients receiving thiazide diuretics as an adjunct to various other hypotensive drugs showed that although the introduction of thiazide treatment might lead to marked elevation of plasma renin concentration this seemed independent of changes in plasma potassium. No significant relationship was found between plasma renin and plasma potassium concentration in these cases (77 observations in 60 patients ; $\mathrm{r}=-0.079 ; \mathrm{P}>0.1)$. By contrast, the inverse relationship between plasma sodium and plasma renin was highly significant $(r=-0.495 ; \mathrm{P}<0.001)$.

\section{Discussion : Relationship Between Renin Concentration, "Renin Activity," and Angiotensin Concentration}

It is important to appreciate that the results obtained by the present method cannot be directly compared with estimations of what has been termed " renin activity† " (Helmer and Judson, 1963 ; Fitz and Armstrong, 1964 ; Boucher et al., 1964 ; Fasciolo et al., 1964 ; Skinner et al., 1964 ; Veyrat et al., 1964 ; Conn et al., 1964). In these latter systems plasma is incubated in vitro and the angiotensin content estimated after a fixed

\footnotetext{
${ }_{1}^{1}$ Reports from Damascus state that two recent plasma $\mathrm{K}$ results were 2.7 and $3.6 \mathrm{mEq} / 1$. in this case.

"While the term "renin activity" is not used by each of these authors, their methods are comparable.
}

incubation time. The " activity" found is therefore dependent upon both the renin concentration and the substrate concentration of the sample; and Helmer (1964) has pointed out that variations in substrate concentration may be as important physiologically as changes in renin. These methods contrast with the present technique, in which endogenous substrate is eliminated and the extracted renin is incubated with a fixed concentration of a standard substrate (Lever et al., 1964 ; Brown et al., 1964a).

Changes in renin concentration do not necessarily cause similar changes in angiotensin concentration. Equally, the techniques currently in use for the estimation of "renin activity" in vitro do not represent the in vivo activity of the system, since angiotensinases and possibly activators and inhibitors are eliminated in several ways, and the recovery of the two major components on which the reaction depends, renin and its substrate, may vary considerably. These aspects are discussed more fully elsewhere (Lever et al., 1964 ; Brown et al., 1964a, 1964g).

Measurement of plasma angiotensin concentration could well give the most direct information, though even this cannot take into account varying responsiveness at the receptor site. Techniques at present in use for the estimation of angiotensin and "renin activity" in plasma are handicapped also by limitations of sensitivity (Fitz and Armstrong, 1964; Scornik and Paladini, 1964 ; Veyrat et al., 1964 ; Boucher et al., 1964 ; Brown et al., 1965d, 1965f).

Measurement of renin concentration, "renin activity," and angiotensin should at present be regarded as complementary. Where findings with these various methods apparently conflict, the very considerable differences between the techniques must be appreciated, together with the fact that of ten quite different components of the system are being studied.

Although a correlation between plasma sodium and either " renin activity" or angiotensin does not appear to have been made, it is notable that Kirkendall et al. (1964), using the method of Helmer and Judson (1963), found plasma " renin activity" low or undetectable before operation in a patient with an aldosterone-producing adenoma. Renin activity rose after removal of the tumour. Conn et al. (1964), using the extraction procedure of Boucher et al. (1964), subsequently reported similar findings. Plasma sodium levels were not reported, however, in any of these cases.

Kirkendall et al. (1964) also found an increase in mean " renin activity" in patients with renovascular and malignant hypertension, with a tendency to a lower serum sodium in the latter group. Other workers have obtained a wide range of results for " renin activity" in patients with renal artery stenosis or malignant hypertension (Conn et al., 1964 ; Genest et al., 1964 ; Helmer, 1964 ; Veyrat et al., 1964).

While plasma angiotensin has usually been undetectable in patients with primary aldosteronism (Biron et al., 1962 ; Morris et al., 1964), Biron et al. (1962) found measurable levels in the peripheral plasma in one case. In other forms of hypertension plasma angiotensin measurement has given varied results (Kahn et al., 1952 ; Langford and Day, 1961 ; Genest et al., 1964 ; Morris et al., 1964 ; Mulrow, 1964). It is possible that some of these apparent discrepancies might be resolved by studying the relationship between angiotensin and plasma sodium.

The present finding of a constant inverse relationship between plasma renin concentration and plasma sodium, which appears largely independent of the aetiology of the hypertension or of its treatment, suggests very strongly that changes in sodium balance are the cause rather than the result of the wide variations in renin. This probable sequence of events can be seen more clearly when thiazide diuretics are used, and in the treatment of Conn's syndrome with spironolactone. Such an interpretation would be in accord with present concepts of the renin-angiotensin system as a regulator of aldosterone secretion, put forward originally by Gross (1958), and subsequently 
supported by numerous clinical and experimental observations. The dangers in extrapolating from the histological appearances of the juxtaglomerular apparatus to the renin content of the kidney have been previously stressed (Brown et al., 1965e). Moreover, one cannot conclude that the renal content of renin is directly related to that of the plasma. The present results do, nevertheless, recall the observations of Pitcock and Hartroft (1958) that the juxtaglomerular index after death was more closely related to the plasma sodium concentration before death than to the blood-pressure.

These findings in no way exclude the possibility of other influences on plasma renin concentration. For example, in a patient with bronchial carcinoma and inappropriate oversecretion of an antidiuretic hormone, depression of plasma sodium to $115 \mathrm{mEq} / 1$., without a corresponding fall in total exchangeable sodium, was associated with a plasma renin concentration which was consistently in the normal range (Brown et al., 1965a).

The present data do, however, establish in a series of patients with hypertension what appears to be a fundamental interconnexion between renin and sodium. This provides a rational basis for considering the wide variations in plasma renin concentration which occur in relation to aetiology, complications, and treatment. We intend to deal with these aspects in subsequent papers.

\section{Summary}

A total of 399 measurements of plasma renin concentration and plasma electrolytes were made in a series of 253 hypertensive patients. A highly significant inverse relationship was found between renin and sodium. This relationship was independent of aetiology, height of blood-pressure, complications, or treatment. Abnormally low plasma renin was found with the hypernatraemia of Conn's syndrome and Cushing's syndrome; the highest renin concentration occurred in the hyponatraemic syndrome characterized by malignant hypertension, renal disease, and hyperaldosteronism. Hypokalaemia was found with both abnormally high and abnormally low plasma renin concentration.

We are grateful to Professor W. S. Peart for co-operation in the study of many of these patients. Plasma specimens and clinical details were also provided by the following, to whom we extend our thanks: Dr. M. A. Barraclough, Dr. G. M. Berlyne, Mr. L. L. Bromley, Dr. W. D. W. Brooks, Dr. C. L. Cope, Dr. J. Crabbé, Dr. C. T. Dollery, Dr. T. C. Hunt, Professor P. Lauwers, Dr. J. W. Litchfield, Professor J. McMichael, Professor I. H. Mills, Professor M. D. Milne, Professor A. F. Muller, Professor G. W. Pickering, Professor M. Rosenheim, Professor G. A. Smart, Dr. W. B. Thomson, Professor H. E. de Wardener, Dr. O. M. Wrong, and Dr. V. Wynn.

Aldosterone measurements were made by Dr. C. L. Cope, Dr. R. V. Brooks, Dr. V. H. T. James, and Mr. Robert Fraser.

Technical help was given by Mr. Patrick Trust, Mr. George Todd, and Mr. Malcolm Tree, and secretarial assistance by Mrs. E. M. Maxwell and Mrs. D. M. Roberts. Many of the electrolyte determinations were performed in the Routine Chemical Pathology Laboratory with the co-operation of Dr. B. J. Houghton.

This work was supported by grants from the Medical Research Council, the Wellcome Trust, and Pfizer Ltd.

\section{REFERENCES}

Barraclough, M. A., Bacchus, B., Brown, J. J., Davies, D. L., Lever, A. F., and Robertson, J. I. S. (1965). To be published. Barter, F. C., Casper, A. G. T., Delea, C. S., and Slater, J. D. H. (1961).
Metabolism, 10, 1006.

Bauer, H., and Forbes, G. L. (1952). Amer. Heart 7., 44, 634.

Biron, P., Chretien, M., Koiw, E., and Genest, J. (1962). Brit. med. F. 1. 1569 .

Blair-West, J. R., Coghlan, J. P., Denton, D. A., Goding, J. R., Munro, J. A., Peterson, R. E., and Wintour, M. (1962). F. clin. Invest., 41, 1606.
Blacquier, P., Bohr, D. F., and Hoobler, S. W. (1960). Amer. F. Physiol., 198, 1148 .

Boucher, R., Veyrat, R., de Champlain, J., and Genest, J. (1964). Canad. med. Ass. F., 90, 194.

Braun-Menéndez, E., Fasciolo, J. C., Leloir, L. F., Munoz, J. M., and Taquini, A. C. (1946). Renal Hypertension, translated by L. Dexter. Thomas, Springfield.

Brooks, R. V. (1960). Mem. Soc. Endocr., 8, 9.

Brown, J. J., Davies, D. L., Lever, A. F., and Robertson, J. I. S. (1963a). Lancet, 2, 278.

(1963b). In Boerhaave Course: Hypertension, edited by J. de Graeff, pp. 40, 44, 216. Leyden University.

- - and Tree, M. (1964a). Biochem. 7., 93, 594.

- (1964c). In Aldosterone, edited by E. Baulieu and F. Robel, pp. 453-469. Blackwell, Oxford.

- (1964d). F. Physiol. (Lond.), 173, 408.

二- Peart, W. S., and Robertson, J. I. S. (1964f). Brit. med. $x, 2,1636$.

7., 93, 3C. Robertson, J. I. S., and Tree, M. (1964g). Biochem. C. (1965a). F. Endocr., 32, v-vii.

- (1965b). To be published.

Endocr. In press. 191,867 .

- Parker, R. A., and Robertson, J. I. S. (1965e). In press. 7. 1,855 Peart, W. S., and Robertson, J. I. S. (1965f). Brit. med.

7., 1, 855.
Conn, J. W. (1955). F. Lab. clin. Med., 45, 3.

Cohen, E. L., and Rovner, D. R. (1964). F. Amer. med. Ass., $190,213$.

Cope, C. L., Nicolis, G., and Fraser, B. (1961). Clin. Sci., 21, 367.

Davis, J. O.' (1962). Physiologist, 5, 65.

Deming, Q. B. (1954). Arch. intern. Med., 93, 197.

Dollery, C. T., Shackman, R., and Shillingford, J. (1959). Brit. med. F., 2,1367 .

Fasciolo, J. C., De Vito, E., Romero, J. C., and Cucchi, J. N. (1964). Canad. med. Ass. F., 90, 206.

Fawcett, J. K., and W ynn, V. (1956). Brit. med. F., 2, 582.

Fitz, A. E., and Armstrong, M. L. (1964). Circulation, 29, 409.

Fitzgerald, M. G., Fourman, P., James, A. H., and Scarborough, H. (1957). Scot. med. F., 2, 473.

Floyer, M. A. (1951). Clin. Sci., 10, 405

Genest, J., Boucher, R., de Champlain, J., Veyrat, R., Chretien, M., Biron, P., Tremblay, G., Roy, P., and Cartier, P. (1964). Canad. med. Ass. F., $90,263$.

(Kbh.), Suppl. 51 , 173.

(Kbh.), Suppl. 51, p. 173.

Nowaczynski, W., Koiw, E., Sandor, T., and Biron, P. (1960b). In Essential Hypertension, edited by K. D. Bock and P. Cottier, p. 126. Springer-Verlag, Berlin.

Goldblatt, H. (1937). Ann. intern. Med., 11, 69.

- (1947). Physiol. Rev., 27, 120.

(1964). Bull. N.Y. Acad. Med., 40, 745

Lynch, J., Hanzal, R. F., and Summerville, W. W. (1934). f. exp. Gowenck,

Gowenloc, A. H., and Wrong, O. (1962). Quart. F. Med., 31, 323.

Gross, F. (1958). Klin. Wschr., 36, 693.

Helmer, O. M., and Judson, W. E. (1963). Circulation, 27, 1050.

(1964). Canad. med. Ass. F., 90, 221.

Holten, C., and Petersen, V. P. (1956). Lancet, 2, 918

Kahn. J. R., Skeggs L. T., Shumway, N. P., and Wisenbaugh, P. E., (1952). F. exp. Med., 95, 523.

Kirkendall, W. M., Fitz, A., and Armstrong, M. L. (1964). Dis. Chest, $45,337$.

Kliman, B., and Petersen, R. E. (1960). 7. biol. Chem., 235, 1639.

Langford, H. G. (1963). Perspect. Biol. Med., 6, 372.

- and Day, L. H. (1961). Clin. Res., 9, 203.

Laragh, J. H., Angers, M., Kelly, W. G., and Lieberman, S. (1960a). F. Amer, med. Ass., 174, 234.

Ulick, S., Januszewicz, V., Deming, Q. B., Kelly, W. G., and Lieberman, S. (1960b). F. clin. Invest., 39, 1091.

Lever, A. F., Robertson, J. I. S., and Tree, M. (1963). Mem. Soc. Endocr., 13, 285.

Morris, R. E., Robinson. Biochem. 7., 91, 346.

rris, R. E., Robinson, P. R., and Scheele, G. A. (1964). Canad. med. Ass. f., $90,272$.

Mulrow, P. J. (1964). Ibid., 90, 277.

and Ganong, W. F. (1961). Yale 7. Biol. Med., 33, 386.

Page I. Cera, G., and Kuliian, A. (1962). F. clin. Invest., 41, 505.

Peart, W. S., Robertson, J. I. S., and Grahame-Smith, D. G. (1961). Circulat. Res., 9, 1171.

Pickering, G. W., and Peart, W. S. (1964). In-Biochemical Disorders in Human Disease, edited by R. H. S. Thompson and E. J. King, 2nd Human Disease, edited by R. H.
ed., p. 243. Churchill, London.

ed., p. 243. Churchill, London.

Pitcock, J. A., and Hartroft, P. M. (1958). Amer. F. Path., 34, 863. 526. (1964). Canad. med. Ass. F., 90, 269.

Skinner, S. L., McCubbin, J. W., and Page, I. H. (1964). Circulat. Res., $15,522$.

Tigerstedt, R., and Bergman, P. G. (1898). Skand. Arch. Physiol., 8, 223.

Veyrat, R., de Champlain, J., Boucher, R., and Genest, J. (1964). Canad. med. Ass. F., 90, 215.

Wootton. I. D. P., and King, E. J. (1953). Lancet, 1, 470.

Wrong, O. (1957). Quart. F. Med., 26, 586.

W yngaarden, J. B., Keitel, H. G., and Isselbacher, K. (1954). New Engl. f. Med., 250, 597.

Yamauchi, H., Biglieri, E. G., and Hopper, J. (1961). Proc. Soc. exp. Biol.'(N.Y.), 107, 728 . 